\title{
Retraction: detection and differentiation of borrelia burgdorferi sensu lato in ticks collected from sheep and cattle in China
}

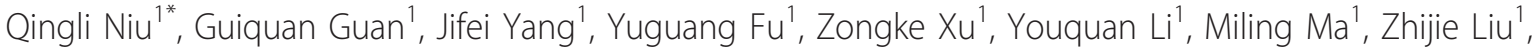
Junlong Liu', Aihong Liu', Qiaoyun Ren', Wayne Jorgensen², Jianxun Luo ${ }^{1}$ and Hong Yin ${ }^{1}$

\section{Retraction}

This article [1] has been regretfully retracted due to plagiarism by the authors. The method for the identification of Borrelia burgdorferi sensu lato species in ticks presented in the article was originally developed and published by Sjoerd Rijpkema and colleagues [2]. The authors apologise to all affected parties for the inconvenience caused.

\begin{abstract}
Author details
'State Key Laboratory of Veterinary Etiological Biology, Key Laboratory of Veterinary Parasitology of Gansu Province, Key Laboratory of Grazing Animal Diseases MOA, Lanzhou Veterinary Research Institute, Chinese Academy of Agricultural Sciences, Lanzhou 730046, China. ${ }^{2}$ Centre of Animal Science, QAAFI, University of Queensland 4072 Australia.
\end{abstract}

Received: 8 September 2011 Accepted: 20 September 2011

Published: 20 September 2011

\section{References}

1. Niu Q, Guan G, Yang J, Fu Y, Xu Z, Li Y, Miling Ma1, Liu Z, Liu J, Liu A, Ren Q, Jorgensen W, Luo J, Yin H: Detection and differentiation of Borrelia burgdorferi sensu lato in ticks collected from sheep and cattle in China. BMC Veterinary Research 2011, 7:17.

2. Rijpkema SG, Molkenboer MJ, Schouls LM, Jongejan F, Schellekens JF: Simultaneous Detection and Genotyping of Three Genomic Groups of Borrelia burgdorferi Sensu Lato in Dutch Ixodes ricinus Ticks by Characterization of the Amplified Intergenic Spacer Region between 5S and 23 S rRNA Genes. J Clin Microbiol 1995, 33(12):3091-5.

doi:10.1186/1746-6148-7-56

Cite this article as: Niu et al:: Retraction: detection and differentiation of borrelia burgdorferi sensu lato in ticks collected from sheep and cattle in China. BMC Veterinary Research 2011 7:56.

\footnotetext{
* Correspondence: niuqingli@163.com

'State Key Laboratory of Veterinary Etiological Biology, Key Laboratory of Veterinary Parasitology of Gansu Province, Key Laboratory of Grazing Animal Diseases MOA, Lanzhou Veterinary Research Institute, Chinese Academy of Agricultural Sciences, Lanzhou 730046, China

Full list of author information is available at the end of the article
}

Submit your next manuscript to BioMed Central and take full advantage of:

- Convenient online submission

- Thorough peer review

- No space constraints or color figure charges

- Immediate publication on acceptance

- Inclusion in PubMed, CAS, Scopus and Google Scholar

- Research which is freely available for redistribution

Submit your manuscript at www.biomedcentral.com/submit
() Biomed Central 